\title{
An efficient catalyst-free synthesis of novel chromeno[4,3-b]quinolones through Michael initiated ring closure (MIRC) reaction with in situ generated 3-(arylmethylene)chroman-2,4-diones
}

\author{
SUDESH KUMARI and JITENDER M KHURANA* \\ Department of Chemistry, University of Delhi, Delhi 110 007, India \\ E-mail: jmkhurana1@yahoo.co.in; jmkhurana@chemistry.du.ac.in
}

MS received 3 November 2016; revised 8 May 2017; accepted 9 June 2017

\begin{abstract}
A catalyst-free multicomponent reaction capable of affording a wide range of eighteen novel chromeno[4,3-b]quinolone derivatives (6a-6r) via one-pot two-step domino protocol, in ethylene glycol is reported. Catalyst-free conditions along with green solvent system make the process eco-friendly as well as economical. High yields of the products were obtained in short reaction times by forming three new bonds and one stereocenter in a single operation. The salient features of the present protocol are short reaction times, eco-friendly solvents, high yields and easy work-up procedure.
\end{abstract}

Keywords. Ethylene glycol; 4-hydroxycoumarin; multicomponent reaction; green chemistry.

\section{Introduction}

The Michael Initiated Ring Closure (MIRC) reaction represents a well-designed approach, which has been used extensively for the construction of carbocyclic compounds ${ }^{1}$ and small/medium sized nitrogen ${ }^{2}$ or oxy$\mathrm{gen}^{3}$ containing heterocyclic compounds. The MIRC strategy can also be achieved through catalyst free one-pot multicomponent reactions ${ }^{4}$ which exhibit high atom-economy and selectivity. ${ }^{5}$ MCRs also provide a powerful synthetic tool for the synthesis of diverse and complex molecules including heterocycles. ${ }^{6}$

Solvents such as water, ionic liquids, ethylene glycol, polyethylene glycol and glycerol have appeared as eco-friendly reaction media in catalyst free organic synthesis. ${ }^{7}$ Ethylene glycol has promising physical and chemical properties like high boiling point, negligible vapour pressure, low toxicity, high polarity, biodegradability and also compatibility with most organic and inorganic compounds. Because of these properties it is used as a promising green media in many catalysed/ uncatalysed organic reactions.

Chromenoquinolines exhibit various activities depending on the nature of fusion between the chromone and quinoline rings. Chromeno[2,3- $b]$ quinolinediones act as potent anti-inflammatory agents ${ }^{8}$ and their $\mathrm{Co}(\mathrm{III})$ and $\mathrm{Cr}$ (III) complexes bind with DNA and have potent nuclease activity. ${ }^{9}$ Chromeno[2,3-g] quinoline-3-carboxylates act as anticoccidal drugs. ${ }^{10}$ Tetrahydrochromeno[4,3- $b$ ]quinolines exhibit antiproliferative activity against MDA-MB-231 and MCF-7 breast cancer cell lines. ${ }^{11} 5 H$-Chromeno[3,4- $f$ ] quinolines act as glucocorticoid receptor modulators and selective progesterone receptor modulators. ${ }^{12}$

Our group has been working on the synthesis of novel heterocycles using environmentally benign methodologies. ${ }^{13}$ We have observed that 4-hydroxycoumarin reacts with aromatic aldehydes under catalyst free condition to generate 3-(arylmethylene)chroman-2,4-dione derivatives. These could undergo reaction with carbon nucleophiles such as enaminones through Michael type reaction followed by ring closure reaction leading to chromeno[4,3- $b]$ quinolone derivatives. We have synthesized eighteen novel chromeno[4,3- $b$ ] quinolone derivatives. Recently, Foroumadi and co-workers reported a similar reaction with ammonia instead of aryl amine. ${ }^{14}$

\footnotetext{
*For correspondence
} 


\section{Experimental}

\subsection{General experimental procedures}

All the chemicals were purchased from Sigma-Aldrich or Merck and used as received. Thin layer chromatography (GF254) was used to monitor reaction progress. Melting points were measured on Buchi M-560 melting point apparatus and are uncorrected. IR ( $\mathrm{KBr}$ disk) spectra were recorded on a Perkin-Elmer FTIR spectrophotometer and the values are expressed as $\nu_{\max } / \mathrm{cm}^{-1}$. The ${ }^{1} \mathrm{H}$ NMR and ${ }^{13} \mathrm{C}$ NMR spectra were recorded on Jeol JNM ECX-400P at 400 and $100 \mathrm{MHz}$, respectively, using TMS as internal standard. The chemical shift values are recorded on $\delta$ scale and the coupling constants $(J)$ are in Hz. Mass spectral data were recorded on Bruker Micro TOF Q-II mass spectrometer.

\subsection{Data collection and refinement}

The intensity data for compound $\mathbf{8 a}$ was collected on an Oxford Xcalibur CCD diffractometer equipped with graphite monochromatic $\mathrm{MoK}_{\alpha}$ radiation $(\lambda 0.71073 \AA$ ) at 293(2) K. The multiscan absorption correction was applied. The crystal structure of $\mathbf{8 a}$ was solved by direct methods and refined by full-matrix least squares refinement techniques on F2 using SHELXL-97. ${ }^{15}$ The coordinates of non-hydrogen atoms were refined anisotropically using SHELXL-97. The positions of hydrogen atoms were obtained from difference Fourier maps and were included in the final cycles of refinement. All calculations were done using the Wingx software package. ${ }^{15}$ Complete crystallographic data (excluding factors) of $\mathbf{8 a}$ has been deposited at the Cambridge Crystallographic Data Centre under number CCDC 1506851.

\subsection{General procedure for the synthesis of 7,12-diaryl-10,10-dimethyl-9,10,11,12-tetrahydro-6H- chromeno[4,3-b]quinolone-6,8(7H)-dione derivatives $(6 \mathbf{a}-6 \mathbf{r})$}

A mixture of dimedone (1) $(1.0 \mathrm{mmol})$ and aromatic amine (2) $(1.0 \mathrm{mmol})$ in ethylene glycol $(5 \mathrm{~mL})$ was placed in a $50 \mathrm{~mL}$ round-bottomed flask and the contents were stirred magnetically in an oil bath maintained at $60^{\circ} \mathrm{C}$ for $15 \mathrm{~min}$. 4Hydroxycoumarin (4) (1.0 mmol) and aromatic aldehyde (5) $(1.0 \mathrm{mmol})$ were then added to the reaction mixture and the mixture was stirred at $60^{\circ} \mathrm{C}$ for an appropriate time as indicated in Table 2. The progress of the reaction was monitored by TLC using ethyl acetate: petroleum ether $(30: 70$, v/v) as eluent. After completion of the reaction, the reaction mixture was allowed to cool at room temperature and diluted with water $(5 \mathrm{~mL})$. The solid separated was collected by filtration at pump. The products were purified by recrystallizing from hot ethanol. The products were characterized by ${ }^{1} \mathrm{H}$ NMR, ${ }^{13} \mathrm{C}$ NMR, DEPT, IR and mass spectra.

\section{Results and Discussion}

The present manuscript reports a new, highly efficient, green synthesis of novel 7,12-diaryl-10,10-dimethyl9,10,11,12-tetrahydro-6H-chromeno[4,3- $b$ ]quinolone6,8(7H)-diones via one-pot, two-step domino protocol from dimedone (1), aromatic amines (2), 4hydroxycoumarin (4) and aromatic aldehydes (5) in ethylene glycol at $60^{\circ} \mathrm{C}$. The methodology for the proposed four component reaction was established for the synthesis of $\mathbf{6 a}$ by attempting reactions of dimedone $(1.0 \mathrm{mmol})$, 4-methylaniline $(\mathbf{2 a})(1.0 \mathrm{mmol})$, 4hydroxycoumarin $(1.0 \mathrm{mmol})$ and 4-chlorobenzaldehyde (5a) $(1.0 \mathrm{mmol})$ under different reaction conditions.

The four component reaction was initially attempted in $\mathrm{H}_{2} \mathrm{O}$ under reflux and also in ionic liquids, [Bmim] $\mathrm{Cl}$ and $[\mathrm{Bmim}] \mathrm{BF}_{4}$ at $80^{\circ} \mathrm{C}$. There was no reaction even after $300 \mathrm{~min}$ (Table 1, entries 1-3). The reaction was then explored in glycerol at $80^{\circ} \mathrm{C}$. Progress of the reaction was monitored by TLC (eluent: ethyl acetate: petroleum ether, 30:70, v/v). The reaction was found to be incomplete after $300 \mathrm{~min}$ though it showed the formation of a new product. After work up and separation by column chromatography, desired product 7-(4-chlorophenyl)-10,10-dimethyl-12(4-methylphenyl)-9,10,11,12-tetrahydro-6 $H$-chromeno [4,3- $b$ ] quinolone-6,8(7H)-dione $(6 a)$ was obtained in $13 \%$ yield (Table 1, entry 4 ) (Scheme 1 ).

The reaction was then attempted in PEG-400 and PEG-600 at $80^{\circ} \mathrm{C}$ which yielded $19 \%$ and $17 \%$ of the product 6a, respectively (Table 1, entries 5 and 6). The above reaction was attempted in $\mathrm{H}_{2} \mathrm{O}$ :EtOH (1:1) and $\mathrm{EtOH}$ as solvents under otherwise identical conditions, which was complete in $150 \mathrm{~min}$ and $65 \mathrm{~min}$ and gave only $32 \%$ and $57 \%$ yield of the desired product $\mathbf{6 a}$, respectively (Table 1, entries 7 and 8). When the reaction was explored in ethylene glycol under otherwise identical conditions, it was complete in $40 \mathrm{~min}$ and gave $90 \%$ yield of the desired product 6a (Table 1, entry 9). The reaction attempted in ethylene glycol at $60^{\circ} \mathrm{C}$ was also complete in 45 min and yielded of $91 \%$ of $\mathbf{6 a}$ (Table 1, entry 10).

Thus, condensation of four components in one-pot in the absence of any catalyst using ethylene glycol as reaction medium at $60^{\circ} \mathrm{C}$ appeared to be the optimum reaction condition. Subsequently, reactions were attempted with differently substituted aromatic aldehydes and aromatic amines under optimized conditions. All the reactions were facile and complete in less than 60 min with both electron-rich and electron-deficient aromatic aldehydes and yielded the corresponding desired products 6a-6r in high yields (Scheme 2). All the products were characterized by structural assignments made 
Table 1. Reaction conditions for the synthesis of 7-(4-chlorophenyl)10,10-dimethyl-12-(4-methylphenyl)-9,10,11,12-tetrahydro-6Hchromeno[4,3- $b]$ quinolone-6,8(7H)-dione $(6 \mathrm{a})^{\mathrm{a}}$.

\begin{tabular}{lcccc}
\hline Entry & Solvent & Time $(\mathrm{min})$ & Temp. $\left({ }^{\circ} \mathrm{C}\right)$ & Yield $(\%)$ \\
\hline 1. & $\mathrm{H}_{2} \mathrm{O}$ & 300 & Reflux & No reaction \\
2. & {$[\mathrm{Bmim}] \mathrm{Cl}$} & 300 & 80 & No reaction \\
3. & {$[\mathrm{Bmim}] \mathrm{BF}_{4}$} & 300 & 80 & No reaction \\
4. & Glycerol & 300 & 80 & $13^{\mathrm{b}}$ \\
5. & PEG-400 & 300 & 80 & $19^{\mathrm{b}}$ \\
6. & PEG-600 & 300 & 80 & $17^{\mathrm{b}}$ \\
7. & $\mathrm{H}_{2} \mathrm{O}:$ EtOH $(1: 1, \mathrm{v} / \mathrm{v})$ & 150 & 80 & 32 \\
8. & EtOH & 65 & 80 & 57 \\
9. & Ethylene glycol & 40 & 80 & 90 \\
10. & Ethylene glycol & 45 & 60 & 91 \\
\hline
\end{tabular}

a Reaction of dimedone $(1.0 \mathrm{mmol}), 4$-methylaniline $(1.0 \mathrm{mmol})$, 4hydroxycoumarin $(1.0 \mathrm{mmol})$ and 4-chlorobenzaldehyde $(1.0 \mathrm{mmol})$.

${ }^{\mathrm{b}}$ Incomplete reaction.<smiles>Cc1ccc(NC2=CC(=O)CC(C)(C)C2)cc1NC1=CC(=O)CC(C)(C)C1</smiles>

Scheme 1. Synthesis of compound $6 \mathbf{a}$.<smiles>CCCC(C)C1(C(C)C)CC(=O)C=C(N[Al])C1</smiles><smiles></smiles>

Ethylene glycol, $60^{\circ} \mathrm{C}$<smiles></smiles>

$6 a-6 r$

Scheme 2. Synthesis of 7,12-diaryl-10,10-dimethyl-9,10,11,12-tetrahydro-6H-chromeno[4,3-b]quinolone-6,8(7H)-dione derivatives.

on the basis of ${ }^{1} \mathrm{H}$ NMR, ${ }^{13} \mathrm{C}$ NMR, IR and mass spectra. The results have been compiled in Table 2 .

NMR spectra of compound $\mathbf{6 b}$ showed three singlets at $\delta 0.81,0.95$ and 2.20 for three methyl groups. Four protons of two $\mathrm{CH}_{2}$ groups appeared in the range of $\delta$ 2.39-2.11 and one singlet for one methine proton appeared at $\delta 5.82$. The twelve aromatic protons appeared in the range of $\delta$ 7.04-8.02. Three methyl carbons in ${ }^{13} \mathrm{C}$ NMR appeared at $\delta 21.0,28.1$ and 28.2 and one methine carbon appeared at $\delta 36.6$. Two 
Table 2. Synthesis of 7,12-diaryl-10,10-dimethyl-9,10,11,12tetrahydro- $6 H$-chromeno[4,3-b]quinolone-6,8(7H)-dione derivatives $(6 a-6 r)^{a}$.

\begin{tabular}{lcccc}
\hline Products & $\mathrm{Ar}$ & $\mathrm{Ar}^{\prime}$ & Time (min) & Yield (\%) \\
\hline $\mathbf{6 a}$ & $4-\left(\mathrm{CH}_{3}\right) \mathrm{C}_{6} \mathrm{H}_{4}$ & $4-\mathrm{ClC}_{6} \mathrm{H}_{4}$ & 45 & 91 \\
$\mathbf{6 b}$ & $4-\left(\mathrm{CH}_{3}\right) \mathrm{C}_{6} \mathrm{H}_{4}$ & $4-\left(\mathrm{NO}_{2}\right) \mathrm{C}_{6} \mathrm{H}_{4}$ & 40 & 93 \\
$\mathbf{6 c}$ & $4-\left(\mathrm{CH}_{3}\right) \mathrm{C}_{6} \mathrm{H}_{4}$ & $4-\left(\mathrm{CH}_{3}\right) \mathrm{C}_{6} \mathrm{H}_{4}$ & 50 & 89 \\
$\mathbf{6 d}$ & $4-\left(\mathrm{CH}_{3}\right) \mathrm{C}_{6} \mathrm{H}_{4}$ & $4-\mathrm{BrC}_{6} \mathrm{H}_{4}$ & 45 & 92 \\
$\mathbf{6 e}$ & $4-\mathrm{ClC}_{6} \mathrm{H}_{4}$ & $4-\mathrm{ClC}_{6} \mathrm{H}_{4}$ & 50 & 92 \\
$\mathbf{6 f}$ & $4-\mathrm{ClC}_{6} \mathrm{H}_{4}$ & $4-\left(\mathrm{NO}_{2}\right) \mathrm{C}_{6} \mathrm{H}_{4}$ & 45 & 94 \\
$\mathbf{6 g}$ & $4-\mathrm{Cl}_{6} \mathrm{H}_{4}$ & $4-\left(\mathrm{CH}_{3}\right) \mathrm{C}_{6} \mathrm{H}_{4}$ & 55 & 91 \\
$\mathbf{6 h}$ & $4-\mathrm{ClC}_{6} \mathrm{H}_{4}$ & $4-\mathrm{BrC}_{6} \mathrm{H}_{4}$ & 45 & 92 \\
$\mathbf{6 i}$ & $4-\left(\mathrm{OCH}_{3}\right) \mathrm{C}_{6} \mathrm{H}_{4}$ & $4-\mathrm{ClC}_{6} \mathrm{H}_{4}$ & 55 & 90 \\
$\mathbf{6 j}$ & $4-\left(\mathrm{OCH}_{3}\right) \mathrm{C}_{6} \mathrm{H}_{4}$ & $4-\left(\mathrm{NO}_{2}\right) \mathrm{C}_{6} \mathrm{H}_{4}$ & 50 & 92 \\
$\mathbf{6 k}$ & $4-\left(\mathrm{OCH}_{3}\right) \mathrm{C}_{6} \mathrm{H}_{4}$ & $4-\left(\mathrm{CH}_{3}\right) \mathrm{C}_{6} \mathrm{H}_{4}$ & 60 & 89 \\
$\mathbf{6}$ & $4-\left(\mathrm{OCH}_{3}\right) \mathrm{C}_{6} \mathrm{H}_{4}$ & $4-\mathrm{BrC}_{6} \mathrm{H}_{4}$ & 55 & 90 \\
$\mathbf{6 m}$ & $\mathrm{C}_{6} \mathrm{H}_{5}$ & $4-\mathrm{ClC}_{6} \mathrm{H}_{4}$ & 55 & 89 \\
$\mathbf{6 n}$ & $\mathrm{C}_{6} \mathrm{H}_{5}$ & $4-\left(\mathrm{NO}_{2}\right) \mathrm{C}_{6} \mathrm{H}_{4}$ & 45 & 91 \\
$\mathbf{6 o}$ & $\mathrm{C}_{6} \mathrm{H}_{5}$ & $4-\left(\mathrm{CH}_{3}\right) \mathrm{C}_{6} \mathrm{H}_{4}$ & 60 & 88 \\
$\mathbf{6 p}$ & $\mathrm{C}_{6} \mathrm{H}_{5}$ & $4-\mathrm{BrC}_{6} \mathrm{H}_{4}$ & 55 & 90 \\
$\mathbf{6 q}$ & Furan-2-methyl & $4-\mathrm{ClC}_{6} \mathrm{H}_{4}$ & 45 & 91 \\
$\mathbf{6 r}$ & Furan-2-methyl & $4-\left(\mathrm{NO}_{2}\right) \mathrm{C}_{6} \mathrm{H}_{4}$ & 40 & 93 \\
\hline
\end{tabular}

${ }^{a}$ Reactions of dimedone $(1.0 \mathrm{mmol})$, aromatic amines $(1.0 \mathrm{mmol}), 4-$ hydroxycoumarin $(1.0 \mathrm{mmol})$ and aromatic aldehydes $(1.0 \mathrm{mmol})$ in the presence of ethylene glycol at $60^{\circ} \mathrm{C}$.

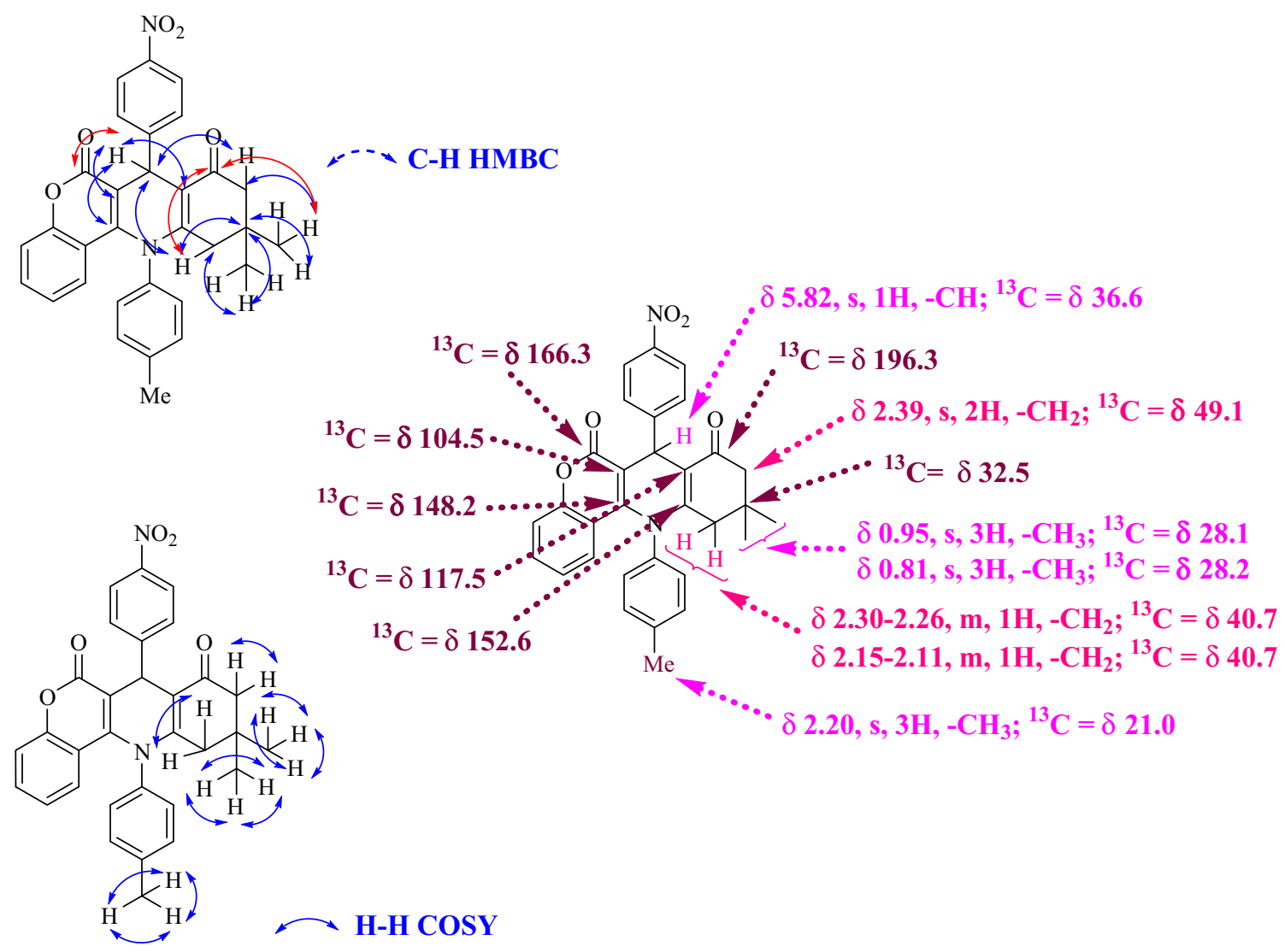

Figure 1. HMBC and COSY correlations of $\mathbf{6 b}$ and characteristic ${ }^{1} \mathrm{H}$ and ${ }^{13} \mathrm{C}$ NMR peaks. 
<smiles>CC1(C)CCC(=CNBr)C(=O)C1</smiles>

3<smiles>N[Mg]</smiles><smiles>CC1(C)CC(=O)CC(=O)C1</smiles><smiles>CC(Br)C=C1C(=O)OC(=O)c2ccccc2C1=O</smiles>

7 $\uparrow \mathrm{Ar}^{\prime}-\mathrm{CHO}$<smiles>O=c1cc(O)c2ccccc2o1</smiles><smiles>CC(C)C1CC(C)(C)CC(=NBr)C1C(Br)c1c(O)c2ccccc2oc1=O</smiles>

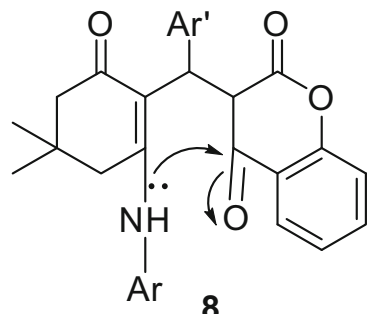<smiles>CC1(C)CC(=O)C2=C(C1)N([Al])c1c(c(=O)oc3ccccc13)C2[Al]</smiles><smiles>CC1(C)CC(=O)C2=C(C1)N([Al])C1(O)c3ccccc3OC(=O)C21CBr</smiles>

6

Scheme 3. Plausible mechanistic pathway for the synthesis of 6a-6r derivatives.

methylene carbons appeared at $\delta 40.7$ and 49.1. The 18 aromatic carbons and 4 olefinic carbons appeared in the range of $\delta$ 104.5-152.6. Two carbonyl carbons appeared at $\delta 166.3$ and 196.3. The position of peaks of methyl, methylene and methine carbons were assigned by DEPT spectra of compound $\mathbf{6} \mathbf{b}$. The two-dimensional NMR spectra and HMBC and COSY correlations are useful in the signal assignment of $\mathbf{6 b}$ and various characteristic signals are shown in Figure 1. IR spectra showed peaks at $2958 \mathrm{~cm}^{-1}$ (C-H stretch), 1656 and $1609 \mathrm{~cm}^{-1}$ (carbonyl stretch), $1567 \mathrm{~cm}^{-1}$ (asymmetric $-\mathrm{NO}_{2}$ stretch) and $1345 \mathrm{~cm}^{-1}$ (symmetric $-\mathrm{NO}_{2}$ stretch). Mass spectrum of $\mathbf{6 b}$ showed a molecular ion peak at $(m / z) 507.1913[\mathrm{M}+\mathrm{H}]^{+}$.

A plausible mechanism involved in the formation of products is outlined in Scheme 3. First step involves condensation of dimedone with aryl amines to form 3(arylamino)-5,5-dimethylcyclohex-2-enone (3) which undergoes Michael addition with in situ generated 3(arylmethylene)chroman-2,4-dione (7) to give an intermediate $\mathbf{8}$. The intermediate $\mathbf{8}$ subsequently undergoes intramolecular cyclisation followed by dehydration to give the final product 5 .

Intermediate 3-((4-chlorophenyl)(2-hydroxy-4,4dimethyl-6-oxocyclohex-1-enyl)methyl)-4-(4-methylphenyl amino)-2H-chromen-2-one (8a) was isolated from the reaction mixture to confirm the mechanism. The structure of compound $\mathbf{8 a}$ was confirmed by ${ }^{1} \mathrm{H}$ NMR, IR, mass spectra and X-ray studies. X-ray crystal structure of 8a is shown in Figure 2. ${ }^{1} \mathrm{H}$ NMR spectrum

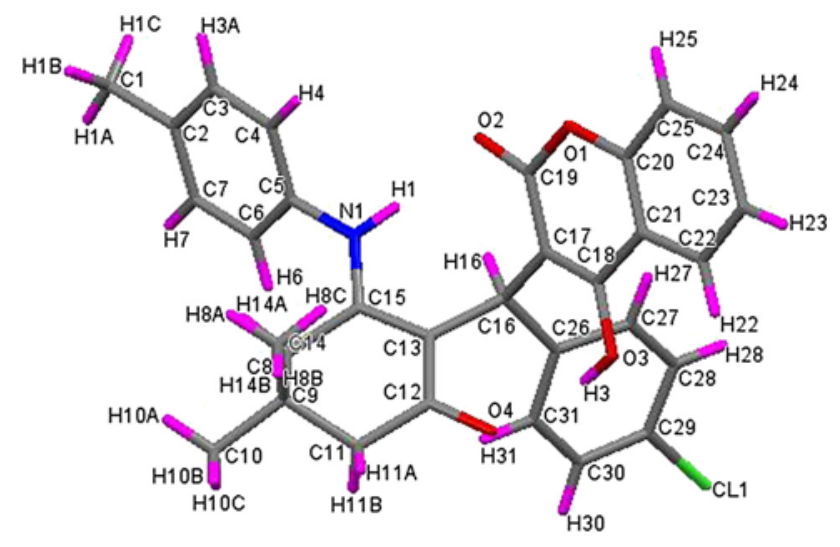

Figure 2. X-ray crystal structure of compound 8a (CCDC-1506851).

of 8a showed a characteristic peak at $\delta 13.75$ for one proton of $\mathrm{OH}$ and at $\delta 10.12$ for one proton of $\mathrm{NH}$. IR spectrum of 8a showed characteristic absorption bands at $3651 \mathrm{~cm}^{-1}$ due to $\mathrm{OH}$ stretch, at $3257 \mathrm{~cm}^{-1}$ due to $\mathrm{NH}$ stretch, at $1663 \mathrm{~cm}^{-1}$ and $1608 \mathrm{~cm}^{-1}$ due to $\mathrm{C}=\mathrm{O}$ stretch of carbonyl. Mass spectrum of 8a showed a molecular ion peak at $(\mathrm{m} / \mathrm{z}) 514.1768[\mathrm{M}+\mathrm{H}]^{+}$. The intermediate $8 \mathbf{a}$ further gave the corresponding product $\mathbf{6 a}$ when heated in ethylene glycol at $60^{\circ} \mathrm{C}$ by intramolecular cyclization (Scheme 4) which confirms the involvement of Michael addition in the above mechanism.

Finally, the recovery and reuse of the reaction medium, ethylene glycol, was examined by using reactions for the synthesis of $\mathbf{6 a}, \mathbf{6 e}$ and $\mathbf{6 i}$. The recyclability of ethylene glycol system was tested by six recycling 


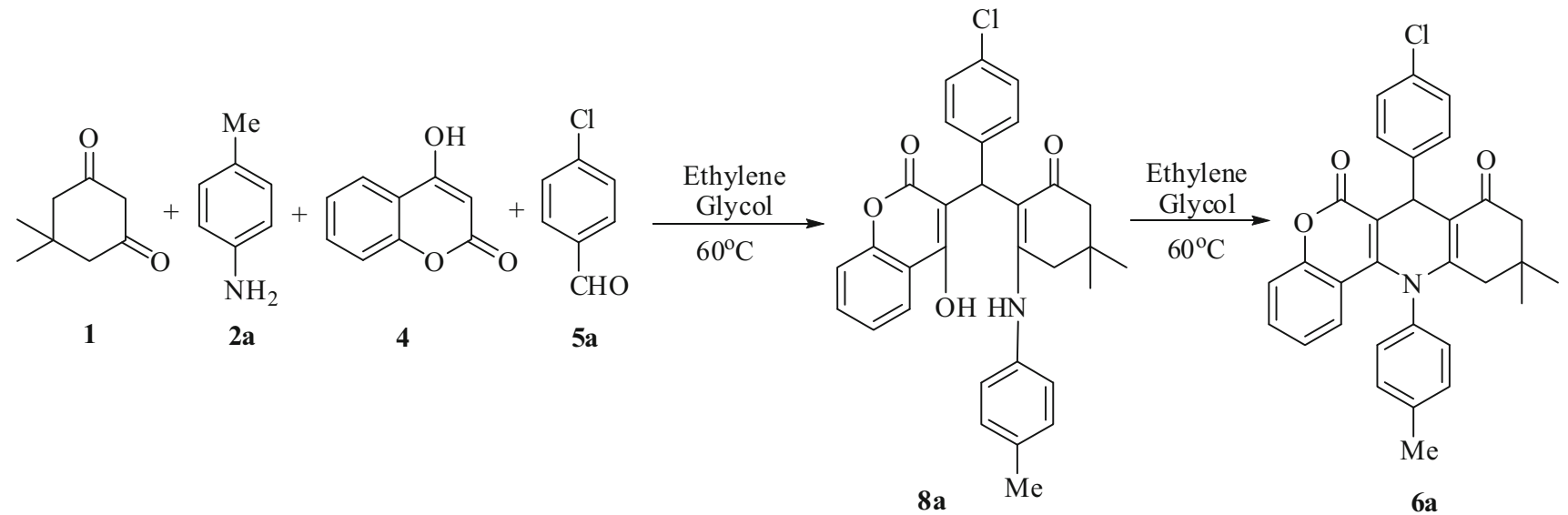

Scheme 4. Synthesis of intermediate $8 \mathbf{a}$ and corresponding product $6 \mathbf{a}$.

Table 3. Recycling of ethylene glycol system for synthesis of compounds $\mathbf{6 a}, \mathbf{6 e}, \mathbf{6 i}$.

\begin{tabular}{lcc}
\hline Run & Yield (\%) & Product \\
\hline 1 & 89 & $\mathbf{6 a}$ \\
2 & 91 & $\mathbf{6 e}$ \\
3 & 88 & $\mathbf{6 i}$ \\
4 & 86 & $\mathbf{6 a}$ \\
5 & 88 & $\mathbf{6 e}$ \\
6 & 85 & $\mathbf{6 i}$ \\
\hline
\end{tabular}

run experiment by changing substrates from one cycle to another cycle. The product was separated from the reaction mixture by simple filtration. This allows quick recovery of the solvent for reuse in the next run. The results of recycling experiment are shown in Table 3. All reactions were complete in 45-65 min and afforded the products in $91-85 \%$ yield. The system showed no substantial reduction in activity. Therefore, this system acts as an excellent recyclable reaction medium for synthesis of novel chromeno[4,3- $b]$ quinolone derivatives in high yields.

\section{Conclusions}

In conclusion, we have developed an efficient, clean and confluent approach for the synthesis of novel 7,12-diaryl-10,10-dimethyl-9,10,11,12-tetrahydro- $6 \mathrm{H}$ chromeno[4,3- $b$ ] quinolone-6, 8(7H)-dione derivatives via reaction of dimedone, aromatic amines, 4hydroxycoumarin and aromatic aldehydes in ethylene glycol at $60^{\circ} \mathrm{C}$. Reactions with heterocyclic amine (furan-2-ylmethanamine) also gave good yields. The protocol is environmentally benign, has a high atomeconomy and offers recyclability of the reaction media.

\section{Supplementary Information}

Complete experimental procedures, spectral data and copies of ${ }^{1} \mathrm{H}$ and ${ }^{13} \mathrm{C}$ NMR of all novel compounds, Figures (S1 and S2) and Tables (S1, S2 and S3) are given in Supplementary Information. Supplementary Information is available at www.ias.ac.in/chemsci.

\section{Acknowledgements}

S.K. thanks the Council of Scientific and Industrial Research, New Delhi, India for the grant of Junior and Senior Research Fellowships. Authors acknowledge University of Delhi for providing Research grant and DST purse grant.

\section{References}

1. Dumez E, Durand A C, Guillaume M, Roger P Y, Faure R, Pons J M, Herbette G, Dulcére J P, Bonne D and Rodriguez J 2009 Michael Addition Initiated Carbocyclization Sequences with Nitroolefins for the Stereoselective Synthesis of Functionalized Heterocyclic and Carbocyclic Systems Chem. Eur. J. 1512470

2. (a) Fioravanti S, Morea S, Morreale A, Pellacani L and Tardella P A 2009 One-pot synthesis of chiral multifunctionalized aziridines Tetrahedron 65 484; (b) Raveendran A E, Paul R R, Suresh E and Nair V 2010 Nucleophilic heterocyclic carbene as a novel catalyst for cyclopropanation of cyano acrylates $\mathrm{Org}$. Biomol. Chem. 8901

3. (a) Wang Q F, Hou H, Hui L and Yan C G 2009 Diastereoselective Synthesis of trans-2,3-Dihydrofurans with Pyridinium Ylide Assisted Tandem Reaction J. Org. Chem. 74 7403; (b) Altieri E, Cordaro M, Grassi G, Risitano F and Scala A 2010 Regio and diastereoselective synthesis of functionalized 2,3-dihydrofuro[3,2c]-coumarins via a one-pot three-component reaction Tetrahedron 669493

4. (a) Tranchant M J and Dalla V 2006 Reaction of vinyl triflates of $\alpha$-O-Benzylhydroxylamino Imides Derived from d-Glyceraldehyde J. Org. Chem. 675957

5. (a) Ruijter E, Scheffelaar R and Orru R V A 2011 Multicomponent Reaction Design in the Quest for Molecular 
Complexity and Diversity Angew. Chem. Int. Ed. 50 6234; (b) Dömling A 2006 Recent developments in isocyanide based multicomponent reactions in Applied Chemistry Chem. Rev. 106 17; (c) Zhu J 2003 Recent Developments in the Isonitrile-Based Multicomponent Synthesis of Heterocycles Eur. J. Org. Chem. 2003 1133; (d) Dömling A and Ugi I 2009 Multicomponent Reactions with Isocyanides Angew. Chem. Int. Ed. 39 3168; (e) Zhu J and Bienayme H 2006 Multicomponent Reactions (Weinheim, Germany: Wiley-VCH); (f) Tietze L F, Brasche G and Gericke K M 2006 In Domino Reactions in Organic Synthesis (Weinheim, Germany: Wiley-VCH)

6. (a) Lie'by-Muller F, Constantieux $\mathrm{T}$ and Rodriguez J 2005 Multicomponent Domino Reaction from $\beta$ Ketoamides: Highly Efficient Access to Original Polyfunctionalized 2,6-Diazabicyclo[2.2.2] octane Cores $J$. Am. Chem. Soc. 127 17176; (b) Chebanov V A, Saraev V E, Desenko S M, Chernenko V N, Knyazeva I V, Groth U, Glasnov T N and Kappe C O 2008 Tuning of chemoand regioselectivities in multicomponent condensations of 5-aminopyrazoles, dimedone, and aldehydes $\mathrm{J}$. Org. Chem. 73 5110; (c) Sunderhaus J D, Dockendorff C and Martin S F 2007 Applications of Multicomponent Reactions for the Synthesis of Diverse Heterocyclic Scaffolds Org. Lett. 94223

7. (a) Hasaninejad A and Firoozi S 2013 Catalyst-free, onepot, three-component synthesis of 5-amino-1,3-aryl-1Hpyrazole-4-carbonitriles in green media Mol. Divers. 17 459; (b) Hasaninejad A, Zare A, Shekouhy M and Rad J A 2010 Catalyst-Free One-Pot Four Component Synthesis of Polysubstituted Imidazoles in Neutral Ionic Liquid 1-Butyl-3-methylimidazolium Bromide J. Comb. Chem. 12 844; (c) Jain S L, Singhal S and Sain B 2007 PEG-assisted solvent and catalyst free synthesis of 3,4dihydropyrimidinones under mild reaction conditions Green Chem. 9740

8. Lim K M, Lee J Y, Lee S M, Bae O N, Noh J Y, Chung S M and Chung J H 2009 Potent anti-inflammatory effects of two quinolinedione compounds, OQ1 and OQ21, mediated by dual inhibition of inducible NO synthase and cyclooxygenase-2 Br. J. Pharmacol. 156 328

9. Sudhamani C N, Naik H S B and Girija D 2012 Synthesis, DNA Binding, and Cleavage Studies of Co(III) Complexes with Fused Aromatic NO/NN-Containing Ligands Nucleosides Nucleotides Nucleic Acids $\mathbf{3 1} 130$

10. Wang Z, Zhou L J, Wang Y L, Weng Y B, He J and Nie K 2011 Synthesis and anticoccidial activities of substituted ethyl 4-hydroxy-11-oxo-11H-chromeno[2,3g]quinoline-3-carboxylates J. Chem. Res. 35373
11. Nagaiah K, Venkatesham A, Srinivasa Rao R, Saddanapu V, Yadav J S, Basha S J, Sarma A V S, Sridhar B and Addlagatta A 2010 Synthesis of new cis-fused tetrahydrochromeno[4,3-b]quinolines and their antiproliferative activity studies against MDA-MB-231 and MCF-7 breast cancer cell lines Bioorg. Med. Chem. Lett. 203259

12. (a) Zhi L, Tegley C M, Pio B, Edwards J P, Jones T D, Marsche K B, Mais D E, Risek B and Schrader W T 2003 Synthesis and biological activity of 5-methylidene 1,2dihydrochromeno[3,4-f]quinoline derivatives as progesterone receptor modulators Bioorg. Med. Chem. Lett. 13 2071; (b) Zhi L, Tegley C M, Kalle E A, Marsche K B, Mais D E, Gottardis M M and Jones T K 1998 5-Aryl1,2-dihydrochromeno[3,4-f]quinolines: A Novel Class of Nonsteroidal Human Progesterone Receptor Agonists J. Med. Chem. 41291

13. (a) Singh H, Sindhu J, Khurana J M, Sharma C and Aneja K R 2014 Ultrasound promoted one pot synthesis of novel fluorescent triazolyl spirocyclic oxindoles using DBU based task specific ionic liquids and their antimicrobial activity Eur. J. Med. Chem. 77 145; (b) Rajeswari M, Sindhu J, Singh H and Khurana J M 2015 An efficient, green synthesis of novel regioselective and stereoselective indan-1,3-dione grafted spirooxindolopyrrolizidine linked 1,2,3-triazoles via a one-pot five-component condensation using PEG-400 RSC Adv. 5 39686; (c) Singh H, Kumari S and Khurana J M 2014 A new green approach for the synthesis of 12-aryl8,9,10,12-tetrahydrobenzo[a] Aust. J. Chem. 69 1049; (f) Kumari S and Singh H and Khurana J M 2016 An efficient green approach for the synthesis of novel triazolyl spirocyclic oxindole derivatives via one-pot five component protocol using DBU as catalyst in PEG-400 Tetrahedron Lett. 57 3081; (g) Rajeswari M, Kumari S and Khurana J M 2016 One-pot four component domino strategy for the synthesis of novel spirooxindole pyrrolizine linked 1,2,3-triazoles via stereo- and regioselective [3+2] cycloaddition reaction in acidic medium RSC Adv. 69297

14. Yahya-Meymandi A, Nikookar H, Moghimi S, Mahdavi M, Firoozpour L, Asadipour A, Ranjbar P R and Foroumadi A 2017 An efficient four-component reaction for the synthesis of chromeno[4,3-b]quinolone derivatives J. Iran. Chem. Soc. 14771

15. (a) Farrugia L J 1997-2009 WinGX Version 1.80.05: An Integrated System of Windows Programs for the solution, Refinement and Analysis of Single Crystal X-Ray Diffraction Data (Glasgow: Department of Chemistry, University of Glasgow); (b) Sheldrick G M 2008 A short history of SHELX Acta Crystallogr. 64112 